\title{
マイクロチャンバー法における換気量変化が DEHP 放散に及ぼす影響 RESEARCH ON DEHP EMISSION UNDER VARYING AIR FLOW VOLUME USING MICRO CHAMBER METHOD
}

\author{
川村 聡宏*1, 波多野弘和*2, 金 炫 兑 ${ }^{* 3}$, 金勲*4, 田辺 新一 *5 \\ Akihiro KAWAMURA, Hirokazu HATANO, Hyuntae KIM, \\ Hoon KIM and Shin-ichi TANABE
}

\begin{abstract}
Semi-volatile organic compounds (SVOC) are contained in building materials including plasticizers and flame retardants, and adverse effects for the human body have been are concerned. It is important to understand of SVOC behavior to reduce exposure risk. The principal aim of this study was to clarify the emission mechanism of DEHP from building materials which is a kind of SVOC. First for some PVC floor tile, emission rates by three methods (FLEC, CLIMPAQ, Little's chamber) and by Micro chamber method were compared. Second experiment was investigated DEHP emission rates from cushion floor under varying air flow volume using micro chamber. In addition, the airflow characteristic of micro chamber was investigated using computational fluid dynamics. Micro chamber method can measure SVOC emission faster than other methods. DEHP emission rate is subject to the airflow velocity near the building-materials surface, the thickness of fluid film under steady state condition.
\end{abstract}

Keywords : Micro chamber, SVOC, DEHP, Computational Fluid Dynamics, Emission rate マイクロチャンバー, 準揮発性有機化合物, フタル酸ビス(2-エチルヘキシル), 数值流体解析, 放散速度

\section{1 はじめに}

淮揮発性有機化合物（SVOC）は沸点が高く、揮発性が低いとい う特性から、短時間での放散量測定が困難であったが、2008 年に JIS A 1904 「建築材料の準揮発性有機化合物（SVOC）の放散測定方 法一マイクロチャンバー法」1) が制定された。SVOC は可塑剤や難 燃剤として様々な建材や家庭用品等に含まれており、喘息やアトピ 一などの健康への影響が懸念されている2）。実空間では気体として 存在する割合が少なく、粉塵などに吸着して重力沈降することが多 いため、気中濃度は低くてもリスクが必ずしも低いとは限らない。 スウェーデンの研究では、ハウスダスト中のフタル酸エステル類の 濃度と子供の喘息やアレルギー症状には、関係性が見られるという 報告 3) がされており、ハウスダスト中 SVOC 濃度への注目が高ま っている。また国内外で一部のSVOC に関して有害性やリスク評価 が行われる中 4)、正確な曝露評価を行うため室内における SVOC 挙動メカニズムを知る必要がある。

著者らのグループでは室内の SVOC の存在を把握するため、ハウ スダスト中 SVOC 濃度測定を行ってきた $\left.{ }^{5}\right) 。$ 延べ 30 軒以上の実測 データからハウスダスト中 SVOC 濃度は、使用される床材の種類に 強く依存していることが示唆され、SVOC を摂取するリスクを低減
するためには建材からのSVOC放散に関する知見を得ることが重要 であることがわかった。一方、Littleらはチャンバー内換気量の増 加6)によって、建材からのSVOC放散速度が変化することを示してい る。しかし、チャンバー内の気流性状とSVOC放散の詳細な関係性 についてのデータは少なく、検討の余地がある。どのようなパラメ 一タの変化がSVOC放散挙動に影響を与えているのか、未だ知見が 不足している。

表面境界上に吸着・蓄積するというSVOCの特質から、各種の素 材に対する吸着性状に関するデータが必要である。そのため、各 SVOC測定チャンバーの特徴、吸着性状について検討を行った。海 外の形状の違うチャンバー (FLEC、CLIMPAQ、Little's chamber) で測定された建材と同じ建材をマイクロチャンバー法で測定するこ とにより、各測定法のパラメータの違いが放散速度に及ぼす作用や、 マイクロチャンバーの特徴について把握した。その後、マイクロチ ヤンバーを用いて換気量の増減が建材からのSVOC放散速度に与え る影響について実験・検討を行った。さらに詳細な考察を行うため、 チャンバー内気流性状の数值流体解析を行った。なお、本論では SVOCの中でも特に生産量が多く、汎用性の高いDEHPに着目した。
*1 清水建設株) 修士 (工学)

*2 早稲田大学大学院創造理工学研究科建築学専攻 修士課程

*3 早稲田大学理工学術院理工学研究所 助手. 博士 (工学)

*4 早稲田大学理工学術院理工学研究所 講師 · 博士 (工学)

*5 早稲田大学理工学術院建築学科 教授. 工博
Shimizu Corporation, M. Eng.

Graduate Student, Dept. of Architecture, Waseda University

Research Assoc., Dept. of Architecture, Waseda University, Dr. Eng.

Lecturer, Department of Architecture, Waseda University, Dr. Eng.

Prof., Department of Architecture, Waseda University, Dr. Eng. 
2 マイクロチャンバー法と海外測定法比較

\section{1 実験概要・目的}

表 1 に測定条件、図 1 にマイクロチャンバー概要、図 2 に Little により考案されたチャンバー（以下、Little チャンバー）、FLEC、 CLIMPAQ を示す。各 SVOC 測定チャンバーで測定された建材 (デ ンマーク製ビニル床材）を入手し、マイクロチャンバー法で測定し た。その結果を各既往研究と比較検討を行った。本実験はマイクロ チャンバーの特徵の確認、チャンバーの各パラメータの違いから SVOC の性質の検討を目的として実験を行った。

\section{2 実験方法}

マイクロチャンバーを水洗いし、メタノールで拭き取り洗浄した 後、加熱装置を用いて、260[ $\left.{ }^{\circ} \mathrm{C}\right] 、 2$ 時間のエージングを行った。そ の後、試験片を設置して密閉し、マイクロチャンバーの排気口に Tenax-TA 捕集管を装着させた状態で、温度 $22 \pm 0.5\left[{ }^{\circ} \mathrm{C}\right.$ ]、相対湿度 $50 \pm 5[\% R H]$ に制御できる恒温湿槽で 24 時間放散試験を行った。温 度条件は海外測定法と合わせた。チャンバー内空気は $15[\mathrm{ml} / \mathrm{min}]$ の流量の不活性ガスを使用した。その後 PVC シート試験片は取り 除き、加熱脱着装置にてマイクロチャンバー内に吸着した SVOCを 加熱脱着する。放散試験と加熱脱着試験の Tenax-TA 捕集管を GC/MS で定性定量し、その結果を合算させ放散量を得る。測定時 間は $6 、 12 、 48 、 72 、 168$ 時間の条件についても測定を行った。分 析対象物質は D6, BHT, DEP, C16, TBP, TCEP, DBA, DBP, C20, TPP, DOA, DEHP の SVOC12 物質と DEHP の加水分解物質である $2 \mathrm{E} 1 \mathrm{H}$ を加えた 13 物質とし、GC/MS により測定した。

\section{3 物質収支モデル}

マイクロチャンバー法からの SVOC 放散速度算出を、Little が提 案したチャンバー内物質収支式(1) 6)から求める。清浄空気を導入し ているため、浮遊粒子と導入気中濃度は $\mathrm{q}_{\mathrm{p}(\mathrm{t})}=\mathrm{C}_{\mathrm{in}(\mathrm{t})}=0$ と仮定した。 また、チャンバー内が定常状態であることを仮定し、式 (2) に Little のモデルを本実験へ対応させた式を示す。式（3）によって求めら れる $\mathrm{k}$ は、「空気中に存在する単位体積当たりのSVOC 量」に対す る「チャンバー内表面への単位面積当たりのSVOC 吸着量」の比率 (以下、分配係数) を表している。分配係数を把握することによっ て、各測定チャンバー内表面の吸着性状について考察を行う。

\section{4 各チャンバーの測定条件比較}

表 2 に各チャンバーの試験条件を示す。各チャンバーの DEHP 放散速度の比較のため採用された PVC シート試験片は Little から 入手した床材であり、Little チャンバー法 7)、FLEC 法 8)、CLIMPAQ 法 8)で測定した試験片と同じものである。

1) Little チャンバー7)

チャンバー内に $0.45[\mathrm{~m}]$ 四方に切断された建材試験片を用いて放 散測定は行われた。チャンバーは内側表面を電解研磨したステンレ ス鋼（SUS304）で作られた。チャンバーリングは 2 つの試験片の 間に設置し、試験片はリングと SS 板によって挟んで設置される。 メタノールで洗浄された $3 つ$ の 304 ステンレス鋼製の棒(直径 $3 \mathrm{~mm}$ ×長さ $60 \mathrm{~mm}$ ）がチャンバー内に挿入され、定期的に表面に吸着し た濃度を測定している。テスト条件は、温度 $22\left[{ }^{\circ} \mathrm{C}\right]$ 、流量 $850[\mathrm{ml} / \mathrm{min}]$ の不活性ガスを流している。気中濃度とステンレス棒 表面濃度を測定し、結果を合算することで SVOC 放散速度が算出さ れている。
表 1 測定条件

\begin{tabular}{|c|c|c|c|c|}
\hline 条件名 & 設定温度 & 測定時間 & 測定回数 & 備考 \\
\hline BL-22 & \multirow{7}{*}{$22^{\circ} \mathrm{C}$} & \multirow{2}{*}{$24 \mathrm{~h}$} & 1 & ブランク実験 \\
\hline DK-22 & & & 3 & \multirow{6}{*}{$\begin{array}{c}\text { デンマーク製 } \\
\text { ビニル床材 } \\
\text { 測定 } \\
\text { (PVC シート) }\end{array}$} \\
\hline DK-22-6 & & $6 \mathrm{~h}$ & \multirow{5}{*}{1} & \\
\hline DK-22-12 & & $12 \mathrm{~h}$ & & \\
\hline DK-22-48 & & $48 \mathrm{~h}$ & & \\
\hline DK-22-72 & & $72 \mathrm{~h}$ & & \\
\hline DK-22-168 & & 168h(1 week $)$ & & \\
\hline
\end{tabular}

マイクロチャンバー詳細

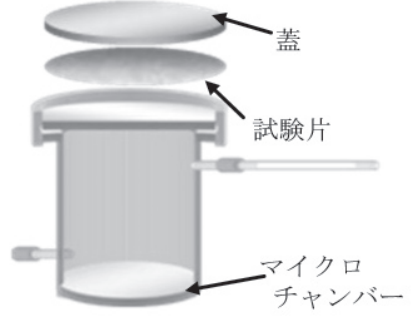

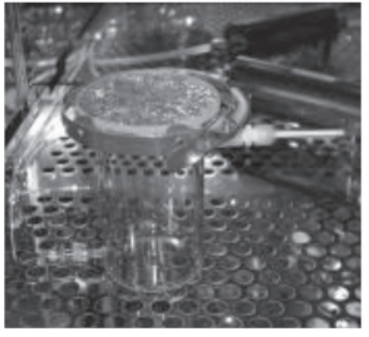

測定風景
図 1 マイクロチャンバー概要

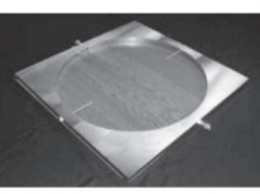

Little チャンバー

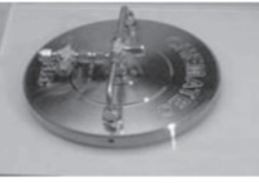

FLEC

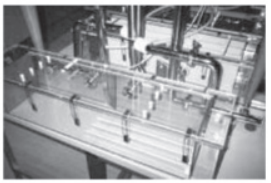

CLIMPAQ
図 2 各 SVOC 測定チャンバー概観

$$
\begin{gathered}
\frac{d C_{(t)}}{d t} V=Q C_{i n(t)}-A_{i} \frac{d q_{(t)}}{d t}-V \frac{d q_{p(t)}}{d t}+A_{s} \dot{m}_{(t)}-Q C_{(t)}-Q q_{p(t)} \ldots \\
\int A_{s} \dot{m}(t) d t \doteqdot \int\left(A_{i} \frac{d q_{(t)}}{d t}+Q C_{(t)}\right) d t \\
k=\frac{\int q_{(t)} d t}{\bar{C}}
\end{gathered}
$$

$C(t) \quad:$ 気中濃度 $\left[\mu \mathrm{g} / \mathrm{m}^{3}\right]$

$V \quad:$ チャンバー内容積 $\left[\mathrm{m}^{3}\right]$

$Q \quad$ : チャンバーの換気量 $\left[\mathrm{m}^{3} / \mathrm{h}\right]$

$A_{i} \quad:$ チャンバー内吸着面積 $\left[\mathrm{m}^{2}\right]$

$\dot{m}$ : 放散速度 $\left[\mu \mathrm{g} / \mathrm{m}^{2} \cdot \mathrm{h}\right]$

$A_{s} \quad$ : 放散面積 $\left[\mathrm{m}^{2}\right]$

$q_{(t)} \quad$ : 時間当たりのチャンバー内表面吸着量 $\left[\mu \mathrm{g} / \mathrm{m}^{2} \cdot \mathrm{h}\right]$

$q_{p(t)} \quad$ : 時間当たりの浮遊粒子吸着量 $\left[\mu \mathrm{g} / \mathrm{m}^{3} \cdot \mathrm{h}\right]$

$k$ : 測定チャンバー内表面/空気の分配係数 $\left[\mathrm{m}^{3} / \mathrm{m}^{2}\right]$

\begin{tabular}{|c|c|c|c|c|}
\hline パラメータ & $\begin{array}{c}\text { マイクロ } \\
\text { チャンバー }\end{array}$ & $\begin{array}{c}\text { Little } \\
\text { チャンバー }\end{array}$ & FLEC & CLIMPAQ \\
\hline 温度 $\left[{ }^{\circ} \mathrm{C}\right]$ & $22 \pm 0.5$ & $22 \pm 0.2$ & $20.1-23.6$ & 22 \\
\hline 相対湿度 [\%] & $50 \pm 5$ & - & $48-52$ & 50 \\
\hline 容積[ml] & 630 & 2000 & 35 & 51 \\
\hline 流量[ml/min] & 15 & $850 \pm 20$ & $444-465$ & $8300-9400$ \\
\hline 換気回数 $[$ 回/h] $(=\mathrm{n})$ & 1.5 & $25 \pm 1$ & 760-796 & 9.8-11 \\
\hline $\begin{array}{c}\text { 試料負荷率 } \\
{\left[\mathrm{m}^{2} / \mathrm{m}^{3}\right](=\mathrm{L})}\end{array}$ & 8.4 & 130 & 510 & 31 \\
\hline $\mathrm{n} / \mathrm{L}[\mathrm{m} / \mathrm{h}]$ & 0.18 & 0.20 & 1.5 & 0.34 \\
\hline 内表面積 $\left[\mathrm{m}^{2}\right]$ & 0.037 & 0.02 & 0.018 & 1.6 \\
\hline $\begin{array}{l}\text { 内表面積/容積 } \\
{\left[\mathrm{m}^{2} / \mathrm{m}^{3}\right](=\mathrm{La})}\end{array}$ & 59 & 10 & 510 & 59 \\
\hline $\mathrm{n} / \mathrm{La}[\mathrm{m} / \mathrm{h}]$ & 0.025 & 2.5 & 1.5 & 0.18 \\
\hline
\end{tabular}

$\bar{C}$ : 測定期間中チャンバー内平均気中濃度 $\left[\mu \mathrm{g} / \mathrm{m}^{3}\right]$

表 2 各チャンバーの試験条件 
2) $\operatorname{FLEC}^{8)}$

FLEC は研磨されたステンレス鋼製の極小のセルであり、建材面 に設置して建材からの放散速度を測定している。試験片と FLEC 内 表面で円錐状の空間を形成し、O-リングによって建材と FLEC 内の 密閉を保たれた。FLEC 上の端の 2 つの穴から清浄空気が供給され、 FLEC の内側下にある円周状のスリットから建材表面と FLEC 内表 面に沿って気流が生じる。排気は円中央にある排気口からなされた。 測定前に洗浄された FLEC はガラスプレート上に設置され、ブラン ク測定が行われた。流量は 444 465[ml/min]、温度は約 $22\left[{ }^{\circ} \mathrm{C}\right]$ 条件 で行われ、気中濃度の測定は排気口からベントを設け、200[ml/min] で 24 時間の捕集を Tenax-TA 捕集管を用いて行われた。放散速度 は気中濃度に換気量を乗じ、試料負荷率を除して求められている。

\section{3) CLIMPAQ ${ }^{8)}$}

CLIMPAQ はガラスとステンレス鋼、アルミニウムで表面が形成 されているチャンバーである。 $0.2[\mathrm{~m}] \times 0.8[\mathrm{~m}]$ の 5 つの試験片は CLIMPAQ 内に気流方向と平行に設置され、流量 8.3 9.4[1/ min] (換 気回数: 約 10 回 $/ \mathrm{h}$ )、温度 $22\left[{ }^{\circ} \mathrm{C}\right]$ 条件で換気が行われた。ブランク 測定として空の CLIMPAQ の測定も行っており、試験片の投入され た CLIMPAQ と同様に気中濃度が測定されている。気中濃度の測定 は排気口からベントを設け、200[ml/min]で 24 時間の捕集を Tenax-TA 捕集管を用いて行われた。放散速度は FLEC 測定法と同 様に求められている。

\section{5 実験結果・既往研究比較検討}

\section{1）放散速度測定結果}

図 3 に DEHP 放散速度測定結果を示す。放散試験では全条件で 検出限界以下となったため、DEHP 放散速度を加熱脱着試験のみか ら算出を行った。2 4 時間測定については 3 回の平均值である。グラ フ横に標準偏差も示した。マイクロチャンバーの床材からの DEHP 放散速度は $1.7\left[\mu \mathrm{g} / \mathrm{m}^{2} \cdot \mathrm{h}\right]$ 程度の值であった。また、72、168 時間条 件に測定された放散速度が同程度であった。これは 72 時間条件以 降、吸着速度がほぼ一定となったためと考えられる。すなわち、建 材表面から Bulk air の濃度勾配と Bulk air から吸着面の濃度勾配 がそれぞれ一定となり、建材表面や吸着面における気中濃度が一定 となっていることが予想される。マイクロチャンバーで 72、168 時 間条件に測定された DEHP 放散速度は Little チャンバー、 CLIMPAQ で測定された放散速度とほぼ同じであった。定常時にお いて FLEC での放散速度は他のチャンバーより高い值を示した。こ の結果は他のチャンバーより FLEC の試料面積当たりの換気量が 大きいためと考えられる。

\section{2）時間と積算吸着量及び放散速度の関係}

図 4 に積算吸着量と放散速度の経時変化を示す。積算吸着量を試 料面積と時間で除すと放散速度が得られる。DEHPに関して、積算 吸着量は時間の経過と共に増加しており、放散速度は時間経過に伴 い減衰している。この結果は、マイクロチャンバー内表面への初期 吸着速度が大きくなるためと考えられる。4 8 時間条件までの放散速 度は Little チャンバー測定法の初期值に近い值を示した。マイクロ チャンバー法で測定した 72、168 時間条件では、DEHP 放散速度 が $0.5\left[\mu \mathrm{g} / \mathrm{m}^{2} \mathrm{~h}\right]$ 以下となり、 Little チャンバー測定法の定常状態の值 に近い值となった。各測定法において、定常状態に達するまでの期 間（以下、S.T.）は CLIMPAQ、FLEC が 150 日以上、Little チャ
ンバーは約 30 日であるのに対し、マイクロチャンバー法では極め て短い時間での測定が可能になっている。Little らは La（吸着負荷 率）が小さくなると、S.T. が短くなると報告している7)が、実験結 果からは吸着負荷率の小さい Little チャンバーよりもマイクロチャ ンバーの方が S.T. が短いことが予想された。これは、チャンバー 内表面の吸着性状の差異によっても S.T.が異なることを示している。 マイクロチャンバーを用いて放散メカニズムの実験を行う場合、S.T. が非常に短いため、短期間での実験検証に適していると考えられる。 また、定常状態の放散速度は FLEC が最も大きく、次にLittle チャ ンバー、マイクロチャンバー、最も小さいのは CLIMPAQ となった。 これは FLEC が他の方法と比較して、n/L が高いことや、建材表面 の境膜が薄くなっていることが原因として考えられる。 $\mathrm{n} / \mathrm{L}$ は試料 の単位面積当たりの換気量を表す。n/L の増大に伴い、放散面から のSVOC 拡散が大きくなると考えられる。なお文献中では定常状態 の定義は明確に示されていないが、チャンバー内濃度（出口濃度） がほぼ一定となる状態を示していると考えられる。

\section{3）チャンバー表面/空気の分配係数算出結果}

表 3 に各測定チャンバーの分配係数を示す。DEHP は気体として 存在しにくいため、分配係数が高いほど、単位面積当たりの吸着量 が多くなる。Little らは表面の吸着性状によって表面に吸着する DEHP 濃度が変化することを報告 9) しており、各チャンバーの素材 に対しても吸着性状に差異が生じていると考えられる。文献 7)8）か

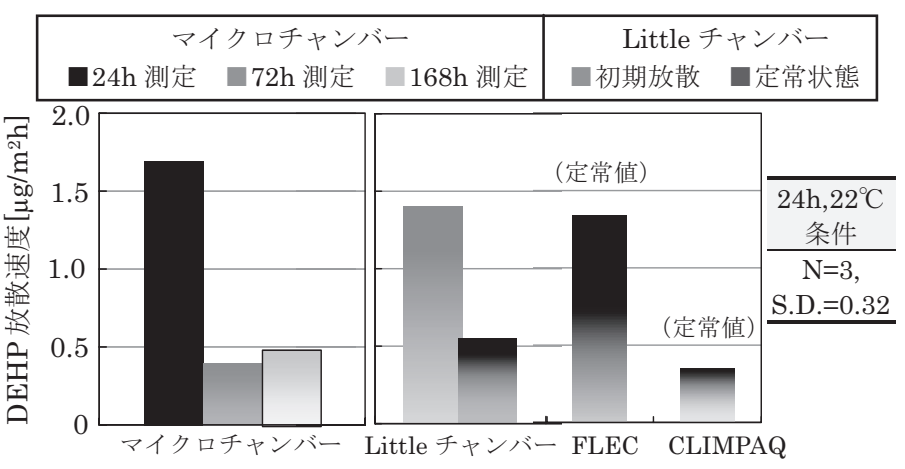

図 3 DEHP 放散速度測定結果

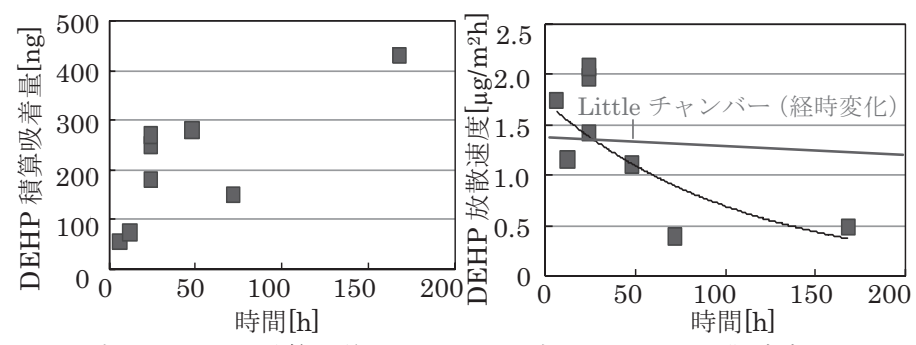

時間と DEHP 積算吸着量の関係時間と DEHP 放散速度の関係 図 4 マイクロチャンバー法による積算吸着量と放散速度の経時変化

表 3 各測定チャンバーの分配係数

\begin{tabular}{|c|c|c|c|}
\hline 測定チャンバー & 分配係数 $\left[\mathrm{m}^{3} / \mathrm{m}^{2}\right]$ & チャンバー素材 & S.T.* \\
\hline マイクロチャンバー & 一**（実測值） & シラン処理ガラス & - \\
\hline Little チャンバー & 1430 (モデル算出值) & ステンレス & 約 30 日 \\
\hline FLEC1 & 4875（実測值） & ステンレス & 約 150 日 \\
\hline FLEC2 & 6056（実測値） & ステンレス & 約 150 日 \\
\hline CLIMPAQ & $2917^{* * * *}$ (参考値) & ガラス & 約 150 日 \\
\hline
\end{tabular}

**気中濃度検出限界以下のため算出ができない ***気中濃度変動が大きいため、測定最終日に得られた值から算出した 
ら各測定チャンバーの分配係数が大きいほど S.T.が長くなる傾向が ある。分配係数が大きいことは、単位吸着面に対する吸着容量が大 きいことを示している。従って、建材からの対象物質の放散により 吸着面が飽和状態（定常状態）になるまでの時間が長くなるためと 考えられる。マイクロチャンバーは 168 時間測定においても、気中 濃度が検出されなかったため、分配係数を算出することが出来なか った。しかし、放散速度が短期間で減衰したため、定常状態時の分 配係数は他のチャンバーと比べ小さな值となることが予測される。 つまり、チャンバー素材であるシラン処理ガラスは脱着性が高く、 DEHP が吸着しづらいことが考えられる。本実験において気中濃度 が検出されなかった原因は、チャンバー内流量が非常に小さく、放 散試験で捕集できた DEHP が検出限界を超えなかったためと考え られた。Little チャンバーと FLEC は同一素材のチャンバーである が、分配係数に差異が生じた。同じ素材であっても素材表面粗度の 差異によって分配係数の值が変化することが考えられる。また素材 ごとの吸着性状の差異を把握するためには $\mathrm{La}$ と $\mathrm{n} / \mathrm{L}$ を調整して実 験する必要がある。

\section{3 換気量変化条件下における DEHP 放散速度試験}

\section{1 実験目的 $\cdot$ 概要}

図 5 に測定概要図、表 4 に測定条件を示す。マイクロチャンバー 法と海外測定法比較により、建材からの DEHP 放散はチャンバー内 の単位試料面積当たりの換気量 $(=\mathrm{n} / \mathrm{L})$ の影響を受けていることが 考えられた。マイクロチャンバーについても $\mathrm{n} / \mathrm{L}$ を上昇させると放 散速度に影響を与えることが予想され、マイクロチャンバー法に準 じた測定では検出されなかった気中濃度も検出される可能性が高い と考えられた。本実験では、短期間での測定に適したマイクロチャ ンバーを用い、換気量を変化させた際の DEHP 放散速度について検 証を行った。また給排気口を逆に使用し、建材表面付近の気流を変 化させた条件についても実験を行った。本実験は詳細なチャンバー 内気流と放散速度の関係の把握を目的として実験、考察を行った。

\section{2 実験方法}

基本的に 2.2 と同様の手順で測定を行う。ただし、測定温度は $28^{\circ} \mathrm{C} 、$ 測定時間は 24 時間とし、換気量条件を変化させる。換気量条件に は 15、70、125、200 [ml/min]条件の 4 条件を設け、それぞれ給排 気口を逆に使用した逆気流条件についても測定を行った。測定対象 建材は市販のPVC 床材を用いた。

\section{3 結果·考察}

図 6 亿換気量変化時の DEHP 放散量、図 7 に換気量と DEHP 放 散速度の関係を示す。DEHP 放散量について、最も低い值を示した のは RV-15 の 751[ng]であり、最も高い值を示したのは RV-200の 1410[ng]であった。VN-15 と VN-200 は放散量に約 100[ng]の差が あり、RV-15 と RV-200の差異は約 550[ng]生じた。逆気流条件の 換気量は放散量に大きく影響を及ぼすことがわかった。換気量と DEHP 放散速度の関係について着目寸ると、正方向気流条件である VN-15から VN-200 までの放散速度はほぼ変化しない結果となった。 これに対し、逆気流条件では換気量の上昇により約 $6\left[\mu \mathrm{g} / \mathrm{m}^{2} \mathrm{~h}\right]$ から $11\left[\mu \mathrm{g} / \mathrm{m}^{2} \mathrm{~h}\right]$ まで上昇した。マイクロチャンバーは正方向気流の場合、 換気量が建材からの放散速度に与える影響が小さく、逆気流条件の 場合、換気量と放散速度は強い関係性があることがわかった。この
原因として、建材からの DEHP 放散は建材表面の気流速度の作用を 受けていることが考えられた。室内において建材近傍の気流速度が 上昇すると、放散速度が上昇する可能性がある。DEHP 曝露リスク 低減のためには換気だけではなく、室内の気流速度分布についても 考慮する必要がある。

気中濃度は正方向気流・逆気流条件共に、 $70[\mathrm{ml} / \mathrm{min}]$ 以上の換気 量条件で検出されたが、15[ml/min]では検出されなかった。70-200 $[\mathrm{ml} / \mathrm{min}]$ における分配係数は、両気流条件で $400\left[\mathrm{~m}^{3} / \mathrm{m}^{2}\right]$ から $2440\left[\mathrm{~m}^{3} / \mathrm{m}^{2}\right]$ の範囲内の值を示し、n/L との関係性は確認できなかっ た。Little, Clausen らの研究 7) 8)において、測定初期の気中濃度は 安定しない結果を示しており、マイクロチャンバーについても定常 状態に達する以前の気中濃度は安定しないことが考えられた。正確 な吸着性状を確認するためには測定期間を長期化する必要がある。

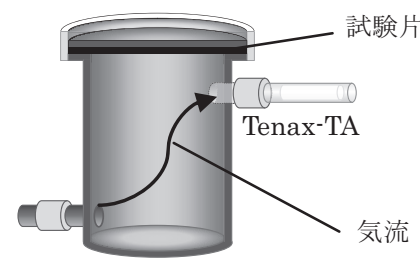

正方向気流条件 (VN)

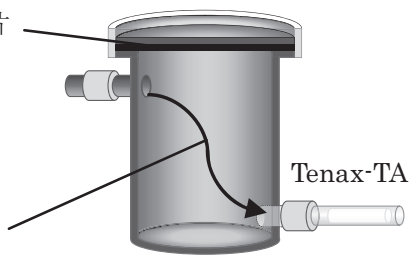

逆気流条件 $(\mathrm{RV})$
図 5 測定概要困

表 4 測定条件

\begin{tabular}{|c|c|c|c|c|c|}
\hline 条件名 & $\begin{array}{l}\text { 温度 } \\
{\left[{ }^{\circ} \mathrm{C}\right]}\end{array}$ & $\begin{array}{c}\text { 換気量 } \\
{[\mathrm{ml} / \mathrm{min}]}\end{array}$ & $\begin{array}{c}\text { 正方向気流 } \\
\text { 測定回数 }\end{array}$ & $\begin{array}{c}\text { 逆気流 } \\
\text { 測定回数 }\end{array}$ & $\begin{array}{c}\mathrm{n} / \mathrm{L} \\
{[\mathrm{m} / \mathrm{h}]}\end{array}$ \\
\hline $\mathrm{BL}$ & \multirow{5}{*}{28} & 15 & 1 & 1 & 0.18 \\
\hline $\mathrm{VN}-15, \mathrm{RV}^{*}-15$ & & 15 & 1 & 2 & 0.18 \\
\hline VN-70, RV-70 & & 70 & 1 & 2 & 0.84 \\
\hline $\mathrm{VN}-125, \mathrm{RV}-125$ & & 125 & 1 & 1 & 1.5 \\
\hline VN-200, RV-200 & & 200 & 1 & 1 & 2.4 \\
\hline
\end{tabular}

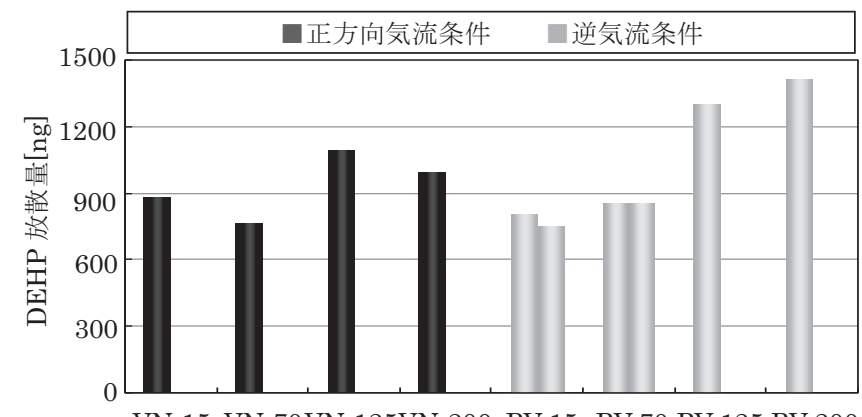

VN-15 VN-70VN-125VN-200 RV-15 RV-70 RV-125 RV-200

図 6 換気量変化条件の DEHP 放散量

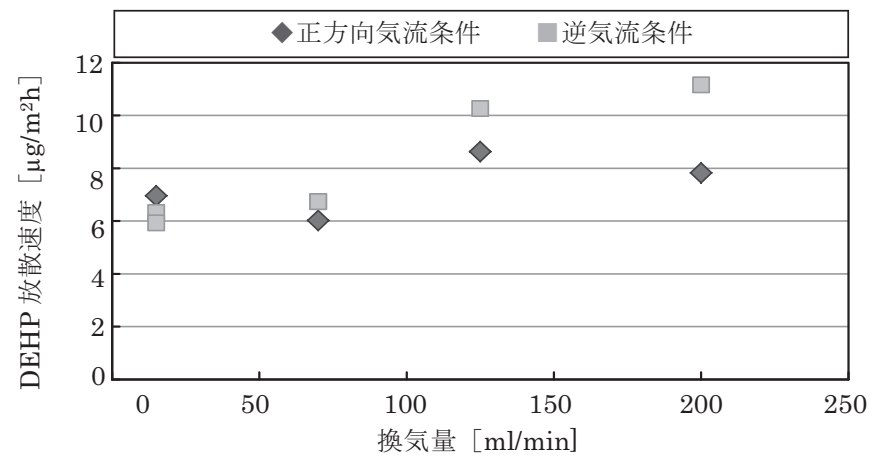

図 7 換気量と DEHP 放散速度の関係 


\section{4 数值流体解析によるチャンバー内気流性状の把握}

\section{1 解析目的}

前章において換気量が DEHP 放散に与える影響について検証し、 DEHP 放散は試験片表面気流速度の影響を受けていることが示唆 された。しかし、実在実験において、給排気流量を変化させた際の マイクロチャンバー内気流性状を正確に把握することは難しい。ま た、勝又らによってチャンバー内気流の検討が行われているが、大 きな換気量の検討は行われていない 10)。そこで本解析は数值流体解 析（CFD 解析）を用いて、試料表面の気流速度、また水蒸気換算の 物質伝達率を算出し、3.3の結果を含めて考察を行った。

\section{2 解析概要}

表 5 に CFD 解析の設定条件を示す。解析ソフトは SCRYU/Tetra version9 用いた。解析領域はマイクロチャンバー内 $($ 幅 $0.124 \mathrm{~m}(\mathrm{X})$ ×奥行 $0.084 \mathrm{~m}(\mathrm{Y}) \times$ 高さ $0.125 \mathrm{~m}(\mathrm{Z})$,容量 $\left.6.3 \times 10^{-4} \mathrm{~m}^{3}\right)$ とし、 外界の影響を受けない設定とした。流量は 15、40、70、125、200、 $250[\mathrm{ml} / \mathrm{min}]$ の 6 条件について、正方向気流条件と逆気流条件の解 析を行った。水蒸気換算の物質伝達率は試験片設置部を水盤と仮定 し、定常状態の水蒸気蒸発量、排気口の相対湿度から算出を行った。 なお、蒸発に使われた潜熱は即座に外界から供給されると仮定し、 水盤面の温度は一定とした。式（4）より物質伝達率を算出し、さ らに式（5）11)、式（6）12)を用いて水蒸気換算の境膜厚さを算出し た。

$$
\begin{aligned}
& k_{c}=\frac{L}{A_{s} \cdot\left(C_{s}-C_{e}\right) \cdot \gamma} \\
& D=D_{0}\left(\frac{T}{T_{0}}\right)^{1.81} \frac{p_{0}}{p} \\
& \Delta x=\frac{D \times 3600}{k_{c}}
\end{aligned}
$$

$k_{c} \quad:$ 物質伝達率 $[\mathrm{m} / \mathrm{h}]$

$L \quad$ : 蒸発量 $[\mathrm{g} / \mathrm{h}]$

$A_{s} \quad$ : 試料面積 $\left[\mathrm{m}^{2}\right]$

$C_{s}$ : 試料面水蒸気含有率 $[-]$ (試料面は飽和状態とし 1 とした)

$C_{e} \quad$ : チャンバー排気口水蒸気含有率 $[-]$

$\gamma \quad$ : 飽和水蒸気量 $\left[\mathrm{g} / \mathrm{m}^{3}\right]$ (本解析では $28^{\circ} \mathrm{C} 、 27.24 \mathrm{~g} / \mathrm{m}^{3}$ )

$D \quad$ : 水蒸気拡散係数 $\left[\mathrm{m}^{2} / \mathrm{s}\right]$ (本解析では $2.70 \times 10^{-5} \mathrm{~m}^{2} / \mathrm{s}$ )

$D_{0} \quad$ : 基準水蒸気拡散係数 $\left[\mathrm{m}^{2} / \mathrm{s}\right]$

$\left(\mathrm{D}_{0}=2.26 \times 10^{-5} \mathrm{~m}^{2} / \mathrm{s} 、 \mathrm{~T}_{0}=273.15 \mathrm{~K} 、 \mathrm{p}_{0}=1.0 \times 10^{5} \mathrm{~Pa}\right.$ を基準とする $)$

$T \quad$ : チャンバー内絶対温度 $[\mathrm{K}](\mathrm{T}=301.15 \mathrm{~K})$

$p \quad$ : チャンバー内気体圧力 $[\mathrm{Pa}]\left(\mathrm{p}=1.0 \times 10^{5}\right)$

$\Delta x \quad$ : 境膜厚さ $[\mathrm{m}]$

\section{3 解析結果 · 考察}

\section{1）チャンバー内気流性状と気流速度}

表 6 に各気流条件における気流速度解析結果、図 8 9 9 に各換気 量条件における数值流体解析結果を示す。正方向気流と逆気流の平 均風速はどの換気量条件においても同程度となった。試料表面風速 （試料面より $5 \mathrm{~mm}$ 垂直に離れた断面のスカラー平均）については 逆気流条件の方が高くなる傾向があるが、15[ml/min]条件では $0.01[\mathrm{~m} / \mathrm{s}]$ 以下の差となった。換気量が小さいほど、表面風速の差も 小さくなるため、 $15[\mathrm{ml} / \mathrm{min}]$ 程度の換気量では放散速度への影響が 小さいことが考えられた。

\section{2）水蒸気換算における単位面積蒸発量と物質伝達率}

図 10 に換気量と水蒸気放散フラックスの関係、換気量と物質伝
表 5 数值流体解析の設定条件

\begin{tabular}{c|c|c}
\hline \multicolumn{2}{|c|}{ 項目 } & 設定 \\
\hline \multirow{4}{*}{ 解析モデル } & 解析条件 & 定常解析 \\
\cline { 2 - 3 } & 解析要素 & 流れ、熱、拡散 \\
\cline { 2 - 3 } & 乱流モデル & 標準 $\mathrm{k}-\varepsilon$ \\
\cline { 2 - 3 } & 目ッシシュ数 & 100000 \\
\hline \multirow{3}{*}{ 流入条件 } & 吹出し流量 & $15 \mathrm{ml} / \mathrm{min} 、 40 \mathrm{ml} / \mathrm{min} 、 70 \mathrm{ml} / \mathrm{min} 、$ \\
\cline { 2 - 3 } & 温湿度 & $25 \mathrm{ml} / \mathrm{min} 、 200 \mathrm{ml} / \mathrm{min} 、 250 \mathrm{ml} / \mathrm{min}$ \\
\hline 流出条件 & 吸込流量 & 表面圧力設定、境界差圧 $0 \mathrm{~Pa}$ \\
\hline
\end{tabular}

表 6 各気流条件における気流速度解析結果

\begin{tabular}{c|c|c|c|c}
\hline \multirow{2}{*}{ 換気量 } & \multicolumn{2}{|c|}{ 正方向気流 } & \multicolumn{2}{c}{ 逆気流 } \\
\cline { 2 - 5 } & $\begin{array}{c}\text { 平均風速 } \\
{[\mathrm{m} / \mathrm{s}]}\end{array}$ & $\begin{array}{c}\text { 試料表面 } \\
\text { 風速 }[\mathrm{m} / \mathrm{s}]\end{array}$ & $\begin{array}{c}\text { 平均風速 } \\
{[\mathrm{m} / \mathrm{s}]}\end{array}$ & $\begin{array}{c}\text { 試料表面 } \\
\text { 風速 }[\mathrm{m} / \mathrm{s}]\end{array}$ \\
\hline $15 \mathrm{ml} / \mathrm{min}$ & $0.70 \times 10^{-4}$ & $0.015 \times 10^{-3}$ & $0.71 \times 10^{-4}$ & $0.013 \times 10^{-3}$ \\
\hline $40 \mathrm{ml} / \mathrm{min}$ & $2.3 \times 10^{-4}$ & $0.040 \times 10^{-3}$ & $2.5 \times 10^{-4}$ & $0.11 \times 10^{-3}$ \\
\hline $70 \mathrm{ml} / \mathrm{min}$ & $7.8 \times 10^{-4}$ & $0.069 \times 10^{-3}$ & $9.6 \times 10^{-4}$ & $0.67 \times 10^{-3}$ \\
\hline $125 \mathrm{ml} / \mathrm{min}$ & $25 \times 10^{-4}$ & $0.11 \times 10^{-3}$ & $30 \times 10^{-4}$ & $2.6 \times 10^{-3}$ \\
\hline $200 \mathrm{ml} / \mathrm{min}$ & $54 \times 10^{-4}$ & $0.23 \times 10^{-3}$ & $58 \times 10^{-4}$ & $5.9 \times 10^{-3}$ \\
\hline $250 \mathrm{ml} / \mathrm{min}$ & $74 \times 10^{-4}$ & $0.44 \times 10^{-3}$ & $77 \times 10^{-4}$ & $8.3 \times 10^{-3}$ \\
\hline
\end{tabular}

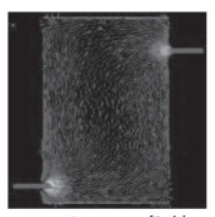

$15 \mathrm{ml} / \mathrm{min}$ 条件

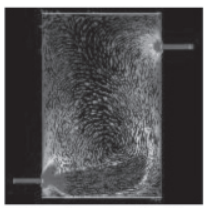

$125 \mathrm{ml} / \mathrm{min}$ 条件

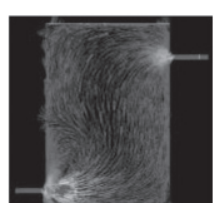

$40 \mathrm{ml} / \mathrm{min}$ 条件

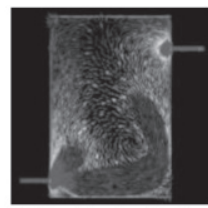

$200 \mathrm{ml} / \mathrm{min}$ 条件

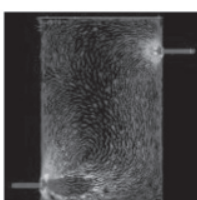

$70 \mathrm{ml} / \mathrm{min}$ 条件

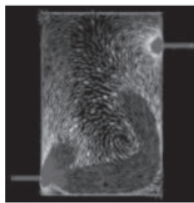

$250 \mathrm{ml} / \mathrm{min}$ 条件

における数值流体解析結果

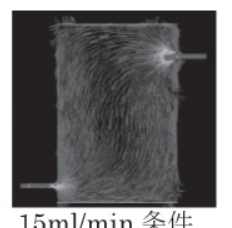

$15 \mathrm{ml} / \mathrm{min}$ 条件

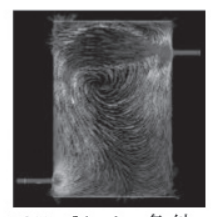

$125 \mathrm{ml} / \mathrm{min}$ 条件
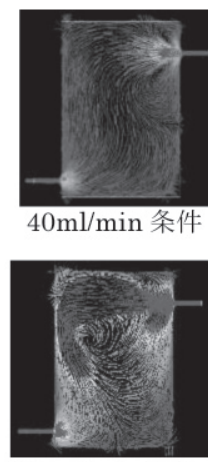

$200 \mathrm{ml} / \mathrm{min}$ 条件

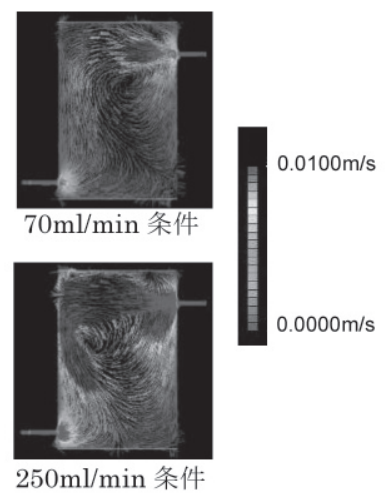

$250 \mathrm{ml} / \mathrm{min}$ 条件
図 9 逆気流換気量 6 条件における数值流体解析結果

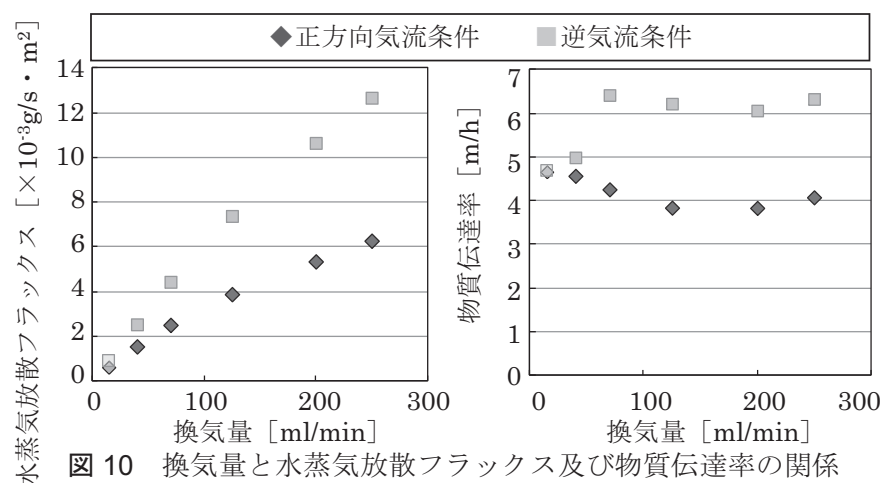


達率の関係、表 7 に境膜厚さ算出結果を示す。換気量の増加に伴い、 放散フラックスも上昇した。逆気流条件は正方向気流条件よりも放 散フラックスが高くなる傾向があり、試料面付近の気流速度が強く 影響していることがわかった。物質伝達率は正方向気流では約 $4[\mathrm{~m} / \mathrm{h}]$ で横ばいとなり、逆気流では $15[\mathrm{ml} / \mathrm{min}] \sim 70[\mathrm{ml} / \mathrm{min}]$ へかけ て上昇し、70[ml/min]以上の換気量から $6[\mathrm{~m} / \mathrm{h}]$ 程度の值で横ばいと なった。物質伝達率は一般的には気流速度の上昇に伴い、高くなる ことが多いが、マイクロチャンバーにおいては上昇しなかった。物 質伝達率は境膜厚さの逆数に比例する值であり、境膜厚さは気流の 状態により変化し試料表面風速が速いほど薄くなることがわかって いる ${ }^{12)}$ 。気流速度が上昇しているにも関わらず境膜厚さが薄くなら ない原因は、試料面近傍の流体濃度が変動しているためである。つ まり $\mathrm{Cs}^{-} \mathrm{Ce}$ (以下、濃度差）が大きくなることによって一定の濃度 勾配と近似できる範囲も大きくなるため、境膜が厚く算出される。 一方で、気流速度の上昇によって境膜が薄くなる作用も働いている ため、一定以上の流量ではお互いの作用が相殺しあい物質伝達率の 変動は小さくなった。逆気流条件の $15[\mathrm{ml} / \mathrm{min}]$ から $70[\mathrm{ml} / \mathrm{min}]$ に おける物質伝達率の上昇は、その条件下では濃度差よりも試料表面 風速が放散速度に強く影響を与えていることを示している。

DEHP については沸点が高く、気体として存在することが難しい 物質であるため、濃度差は流量条件を変えても非常に小さな差異と なることが予想される。そのため、境膜厚さを変動させるパラメー 夕としては建材表面の気流速度が支配的となると考えられる。前章 では、正方向気流条件は建材表面の気流速度の変動が小さかったた め、流量と放散量に相関性が確認されなかった。また逆気流条件で は流量が建材表面の気流速度に強く影響を及ぼすため、流量の上昇 に伴い放散速度も上昇する傾向が表れたと考えられた。

\section{5 まとめ}

本研究は建材からの DEHP 放散メカニズムを調查するに当たり、 同一建材を用いて海外 SVOC 測定チャンバーとマイクロチャンバ 一の比較を行い、マイクロチャンバーの特徵、チャンバーごとの各 パラメータから DEHP の性質について検討した。マイクロチャンバ 一を用いて、換気量が DEHP 放散に与える影響を実験調查し、数值 流体解析と合わせて考察を行った。本研究で得られた知見は以下の とおりである。

1）同じ建材を各 SVOC 測定チャンバーで測定した結果、マイク ロチャンバー法の 24 時間測定が最も高い放散速度を示した。 これは DEHP がチャンバー内濃度の低い初期にチャンバー内 表面への吸着速度が高くなるためである。

2）マイクロチャンバーは各 SVOC 測定チャンバーと比較して、 短期間で建材からの放散速度が減衰し、極めて短い時間での測 定が可能である。

3）チャンバー表面/空気の分配係数と定常状態になるまでの期間 には関係性があり、分配係数が高くなるほど定常となる期間が 長くなることが考えられた。

4）換気量条件を変化させたマイクロチャンバー実験において、換 気量の増加に伴い、建材からの放散速度は正方向気流ではほぼ 変化せず、逆気流では増加する傾向が確認された。

5）建材からの DEHP 放散速度は建材表面の気流速度に依存して
いることがわかった。

6）チャンバー内気流性状を CFD 解析した結果、逆気流では大き く建材表面の気流速度が変化していることがわかった。

7） DEHP 放散速度は Bulk air と放散面の濃度差よりも、建材表 面風速による境膜厚さの変動の影響が大きいと考えられた。

表 7 水蒸気換算境膜厚さ算出結果

\begin{tabular}{c|c|c|c|c}
\hline \multirow{2}{*}{ 換気量 } & \multicolumn{2}{|c|}{ 正方向気流 } & \multicolumn{2}{c}{ 逆気流 } \\
\cline { 2 - 5 } & 境膜厚さ $[\mathrm{m}]$ & $\begin{array}{c}\mathrm{Cs}-\mathrm{Ce} \\
{[\times 100]}\end{array}$ & 境膜厚さ $[\mathrm{m}]$ & $\begin{array}{c}\mathrm{Cs}-\mathrm{Ce} \\
{[\times 100]}\end{array}$ \\
\hline $15 \mathrm{ml} / \mathrm{min}$ & $2.09 \times 10^{-2}$ & 1.75 & $2.07 \times 10^{-2}$ & 2.58 \\
\hline $40 \mathrm{ml} / \mathrm{min}$ & $2.13 \times 10^{-2}$ & 4.48 & $1.95 \times 10^{-2}$ & 6.72 \\
\hline $70 \mathrm{ml} / \mathrm{min}$ & $2.28 \times 10^{-2}$ & 7.79 & $1.51 \times 10^{-2}$ & 9.14 \\
\hline $125 \mathrm{ml} / \mathrm{min}$ & $2.53 \times 10^{-2}$ & 13.4 & $1.56 \times 10^{-2}$ & 15.7 \\
\hline $200 \mathrm{ml} / \mathrm{min}$ & $2.53 \times 10^{-2}$ & 18.5 & $1.60 \times 10^{-2}$ & 23.2 \\
\hline $250 \mathrm{ml} / \mathrm{min}$ & $2.38 \times 10^{-2}$ & 20.4 & $1.53 \times 10^{-2}$ & 26.5 \\
\hline
\end{tabular}

謝辞

本研究の一部は平成 23 年(財) セコム科学技術振興財団調查助成「日 常のみならず被災時の建築空気環境の安全と安心対策」と早稲田大 学理工学研究所「室内空気質と熱的快適性に関する研究」により、 実施致しました。また井口侑香様（元早稲田大学）に多大なご協力 とご助言を頂きました。記して深く謝意を表します。

\section{参考文献}

1） JIS A 1904, 建築材料の準揮発性有機化合物（SVOC）の放散測定方法一 マイクロチャンバー法, 2008

2) M. Wensing, E. Uhde, T. Salthammer: Plastics additives in the indoor environment-flame retardants and plasticzers, Science of the Total Environment 339, pp19-40, 2005

3) C. Bornehag, J. Sundell, C. J. Weschler,: The Association between Asthma and Allergic Symptoms in Children and Phtalates in House Dust: A Nested Case-Control Study, Environmental Health Perspectives, Vol. 112, No. 14, pp 1393-1397, 2004

4） 中西淮子: 詳細リスク評価書シリーズ 1 フタル酸エステルーDEHP一, 丸 善株式会社, 2005

5）金炫允，田辺新一，岡田厚太郎：日本・韓国の住宅における八ウスダス卜 中 DEHP 濃度の測定, 日本建築学会環境系論文集, 第 75 巻, 第 654 号, pp.713-720, 2010,8

6) Ying $\mathrm{Xu}$, John C. Little: Predicting Emissions of SVOCs from Polymeric Materials and Their Interaction with Airborne Particles, Environmental Science \& Technology, pp.456-461, 2006

7) Ying.Xu, T.Park, P.Clausen, V.Kofoed-Sørensen, J.Little: Characterizing emissions of phthalate plasticizer from vinyl flooring in a specially-designed chamber, Epidemiology, Vol.19(6), pp.S294-S295, 2008.11

8) Per Axel Clausen, Vivi Hansen, Lars Gunnarsen, Alireza Afshari, Peder wolkoff: Emission of Di-2-ethylhexyl Phthalate from PVC Flooring into Air and Uptake in Dust: Emission and Sorption Experiments in FLEC and CLIMPAQ, National Institute of Occupational Health, 2004,5

9) John. Little, Ying. Xu, Elaine Cohen Hubal, Per Axel Clausen: Exposure to phthalate emitted from vinyl flooring and sorbed to interior surfaces, dust, airborne particles and human skin, Indoor Air 2008, pp.17-22, 2008.8

10）勝又寛子，村上周三，加藤信介，星野邦弘：マイクロチャンバー法にお ける測定条件の検討, 空気調和・衛生工学会大会学術講演論文集 F-20, 2006

11) C.Richard Tracy, William R. Welch, Warren P. Porter, PROPERTIES OF AIR A Manual for Use in Biophysical Ecology THIRD EDITION, Technical Report No.1, 1980

12）藤井実，甲斐雄也，村瀬陽子，篠原直秀，熊谷一清，落合聖史，常名美貴， 義之信司, 柳沢幸雄: パッシブサンプラー（PFS）を用いた化学物質放散 特性の解析方法, 室内環境学会誌, Vol.7, No.2, pp.17-24, 2004 